\title{
Pathological, molecular and phylogenic study of fowlpox virus in domesticated chickens of Tikrit City, Iraq
}

\section{Estudo patológico, molecular e filogenético do vírus da varíola aviária em frangos de corte domesticados da cidade de Tikrit, Iraque}

\author{
Ismael Ibrahim Hasan $^{1}$ (D); Saad Tawfik Rasheed²; Mohammed Khorshid Shakor ${ }^{3}$ \\ ${ }^{1}$ University of Tikrit, College of Veterinary Medicine, Department of Pathology and Poultry Diseases, Tikrit, Iraq \\ ${ }^{2}$ University of Tikrit, College of Veterinary Medicine, Department of Public Health, Tikrit, Iraq \\ ${ }^{3}$ Slah-adin Educational Veterinary Hospital, Tikrit, Iraq
}

\begin{abstract}
Fowlpox virus (FPV) is one of the viruses affecting chickens worldwide, causing pathological and economic losses in the poultry industry. Viral lesions are easily recognizable by the eye and usually appear in the featherless areas, especially the head. Moreover, the virus could lead to blindness and mortality in some cases. This study diagnosed the suspected fowlpox cases, identified and classified the causative agent. We also analyzed the differences and similarities of closely related viruses at the neighboring and regional countries. Fifty samples were collected from three locations of Tikrit city from the domesticated chickens, which showed cutaneous lesions. Virus DNA was extracted directly from tissue samples before the nested PCR technique was performed. The virion core protein (P4b) gene is partially sequenced and analyzed with routine histological sectioning. Results showed that the virus causes pock lesions of dermal hyperplasia and hyperkeratosis. Hyperplasia and congestion of the chorioallantoic membrane were also recorded. The study also showed that the DNA of FPV could be extracted directly from animal tissue without further purification. The sequence analysis showed that the FPV was confirmed in all samples clustered in clade A identical with Iranian and Egyptian isolates. In conclusion, this study approved that the virus belongs to the classical dermal type of poxviruses and the short genetic distances between viruses related to closely neighboring countries. We also concluded that the conservative P4b gene included mutation sites that make this gene practical for diagnosing the virus and phylogenetic analysis.
\end{abstract}

Keywords: FPV. Skin. Nested PCR. Histopathology. FPV 167.

RESUMO

O vírus da varíola aviária (VVA) é um dos vírus que acometem os frangos de corte em todo o mundo, causando perdas patológicas e econômicas na indústria aviária. As lesões causadas pelo vírus são facilmente reconhecidas pela observação visual e usualmente aparecem nas áreas do corpo das aves livres de penas, especialmente na cabeça. Além disso, em alguns casos a doença pode provocar a cegueira e a mortalidade de animais acometidos. O presente trabalho foi delineado para diagnosticar casos suspeitos de varíola aviária, identificar o agente causal e classificá-lo. Adicionalmente foram analisadas diferenças e similaridades com outros vírus estreitamente relacionados em localidades vizinhas e regionais. Cinquenta amostras foram colhidas em três localidades da cidade de Tikrit de frangos de corte, domesticados, que apresentavam lesões cutâneas. O DNA do vírus foi extraído diretamente das amostras de tecidos antes que a técnica de PCR fosse realizada. As proteínas do core do vírus, gene (P4b), foram parcialmente sequenciadas de analisadas em secções da rotina histológica. Os resultados obtidos revelaram que o vírus causa lesões variólicas com hiperplasia dermal e hiperqueratose. A hiperplasia e a congestão da membrana corioalantóica também foram registradas. O estudo também revelou que o DNA do VVA pode ser extraído diretamente de tecidos animais sem a realização de uma pré-purificação. A análise sequencial revelou que o VVA foi confirmado em todas as amostras agrupando-se em uma classe A, idêntica com isolados iranianos e egípcios. A conclusão obtida foi que o presente trabalho confirmou que o vírus pertence ao tipo dérmico clássico dos poxvirus e que as curtas distâncias genéticas entre os vírus relacionados são encontrados em países vizinhos. Também foi concluído que o gene conservador $\mathrm{P} 4 \mathrm{~b}$ inclui pontos de mutação que o tornam um gene prático para diagnosticar o vírus em análises filogenéticas.

Palavras-chave: Vírus da varíola aviária. Pele. Nested PCR. Histopatologia. VVA167. 
Correspondence to:

Ismael Ibrahim Hasan

University of Tikrit, College of Veterinary Medicine,

Department of Pathology and Poultry Diseases

Tikrit, Iraq

e-mail: Ismailhasan@tu.edu.iq

Received: October 17, 2020

Approved: February 4, 2021

How to cite: Hasan II, Rasheed ST, Shakor MK. Pathological, molecular and phylogenic study of fowlpox virus in domesticated chickens of Tikrit City, Iraq. Braz J Vet Res Anim Sci. 2021;58:e176255. https://doi.org.10.11606/ issn.1678-4456.bjvras.2021.176255

\section{Introduction}

Fowlpox virus is a member of the Poxviridae family that has double-strand DNA (Fenner et al., 1974). The genome of the virus is the largest among viruses (288kbp), with only two complete genome sequences available in the gene bank database (Afonso et al., 2000; Laidlaw \& Skinner, 2004). Over 200 wild and domesticated avian species were reported infected by FPV (Giotis \& Skinner, 2019; Lecis et al., 2019). The cutaneous form of the disease still causes economic losses to the avian industry, even in vaccinated and low mortality flocks (Ferreira et al., 2018). Lesions of poxvirus (Pock) in chicken observe on the wattles, comb, legs, and eyelids (Gilhare et al., 2015). In pigeons, the lesions are seen in the feather and featherless areas of the bird's wing, vent, lower legs, and feet. In Turkey, the lesions are seen at the head, neck, feather areas of the wing, and feet. Depending on the stage of the disease, lesions appear as yellow-brown to black wart-like growths (Lebdah et al., 2019).

Poxvirus causes chorioallantoic membrane hemorrhage, necrosis, hyperplasia, and eosinophilic intracytoplasmic inclusion bodies (Sharma et al., 2019; Soud et al., 2020). Recently, the phylogenetic analysis included a phylogenetic tree, considered a powerful tool to classify FPV isolates worldwide (Murer et al., 2018). Many reports performing FPV phylogenetic analysis used the conservative $\mathrm{P} 4 \mathrm{~b}$ gene, which was published in the late nineteenth century (Binns et al., 1989). Researchers designed primers and developed molecular techniques depending on the $\mathrm{P} 4 \mathrm{~b}$ gene for accurate diagnosis and analysis of FPV (Lee \& Lee, 1997). The locus FPV 167 of the P4b gene is also used for different avian and non-avian species FPV studies (Ruizmart1 et al., 2016; Yeo et al., 2019). The conservative nature of the FPV P4b gene locates centrally in the genome at the position 201502-199532 count for 657 bp., in general, not preferred for phylogenetic tree accuracy (Afonso et al., 2000; Zou \& Zhang, 2016). Recently, differences in the FPV genome between viruses appear fundamentally in an unexpected way in the central region, which is considered as conserved nature (Carulei et al., 2017). In conservative gene probability, researchers may use different reigns of DNA during phylogenetic analysis, the locus FPV 139 and FPV 140 used for this purpose for FPV subclade classifications (Lebdah et al., 2019). This study gathered chickens to identify the suspected FPV cases that appeared locally using routine and molecular methods. The study also aimed to sequence a partial $\mathrm{P} 4 \mathrm{~b}$ gene for genetic analysis and compare between fowl poxviruses in Iraq and neighboring countries, which has not been performed until now in Iraq. The study was also designed to show the possibility of fast and direct virus DNA extraction from animal tissue samples without further purification and multiplication of viruses in embryonated eggs.

\section{Materials and Methods}

\section{Samples collection \& histological preparation}

On Jan-2019, and during the FPV emerging period at Tikrit city, 50 biopsies of skin tissue samples were collected $(n=15)$ from three different locations (five for each site). Part of the skin tissue was stored at $-20^{\circ} \mathrm{C}$ for one week before it was sent to the molecular lab for diagnosis. The other amount of tissue was kept in 10\% formalin and forwarded for routine histological sectioning (Suvarna et al., 2013).

\section{Embryonated Egg inoculation}

Thirty eggs were incubated for 10 days. Inoculum prepared from dermal lesions was inoculated at the Chorioallantoic membrane. Five eggs were not inoculated as a control group (Gilhare et al., 2015). Eggs were harvested after five days, and membranes were sent for routine histological processing (Suvarna et al., 2013).

\section{Viral DNA extraction}

Total virus DNA was extracted from dermal tissue using the Geneaid ${ }^{\text {tix }}$ DNA Isolation Kit. Tissue samples were smashed by surgical blades. The procedure was performed according to the manufacturer's instructions. DNA was dissolved and stored at $-85^{\circ} \mathrm{C}$ until the time of use.

\section{Primers of Virion core protein P4b gene nested PCR amplification}

An external pair of primers P1-F $5^{\prime}$ CAGCAGGTGCTAAACAACAA-3`, P2-R 5` - 
CGGTAGCTTAACGCCGAATA-3 ' were used to amplify 548 bp segment of the locus FPV167 in suspected tissue samples (Lee \& Lee, 1997). For more sensitivity, a pair of internal primers P3-F 5 ' - ACGACCTATGCGTCTTC-3', P4-R 5 - ACGCTTGATATCTGGATG-3` were used to amplify $419 \mathrm{bp}$ fragment from the first PCR product (Fallavena et al., 2002).

\section{Polymerase chain reaction}

Primers (10 pmol of each one) were added to the DNA (100ng/ul) in the premix (Bioneer ${ }^{\oplus}$-Korea) tubes, and the final volume was completed up to $20 \mu \mathrm{l}$ with distilled water. PCR was carried out within thermocycler in which DNA was denatured for $5 \mathrm{~min}$ at $94^{\circ} \mathrm{C}$, followed by 35 cycles of denaturation for $30 \mathrm{sec}$ at $94^{\circ} \mathrm{C}$, annealing at $60^{\circ} \mathrm{C}$ for $\mathrm{P} 1, \mathrm{P} 2$ primers and $52{ }^{\circ} \mathrm{C}$ for $\mathrm{P} 3, \mathrm{P} 4$ primers for $60 \mathrm{sec}$, an extension for $60 \mathrm{sec}$ at $72^{\circ} \mathrm{C}$, and with a final single extension cycle for $5 \mathrm{~min}$ at $72{ }^{\circ} \mathrm{C}$ (Fallavena et al., 2002). DNA electrophoresis was subjected using 1.5\% agarose gel electrophoresis with a $100 \mathrm{bp}$ marker. Agarose gel was stained with Redsafe $e^{\oplus}$ stain. The gel was photographed using a Gel-documentation system.

\section{Phylogenic analysis}

Positive PCR samples sent for Sanger sequencing. Nucleotides sequence of the current study aligned with other sequences published at the GenBank database using the NCBI Blast tool. Nucleotides were used rather than amino acid sequences for determining the genetic diversion. Twelve aligned sequences of FPV isolated from regional countries birds were selected and renamed (accretion number, genus and species name, country of isolation, submission date to Gene Bank). Using MEGA-X software, all nucleotides were aligned by the ClustalW algorithm and trimmed to $486 \mathrm{bp}$. Variable sites in this segment were located, exported, and fitted in a table. Sequences were tested to find the best suitable mathematical model for constricting the Neighbor-Joining (NJ) tree. Tamura 3-parameter model was selected with a gamma distribution parameter value of 0.38 and Bootstrap values of 1000 replicate.

\section{Results}

Gross lesions of the infected chickens (Figure 1A) appeared as classical dermal lesions of pox virus proliferation at the face, especially around the eyes. In some cases, small lesions appeared in the oral cavity, while other dermal lesions appeared on a small scale at unfeathered areas of the chest. Gross lesion of the Chorioallantoic membrane (Figure 1G) visualized as several dark grey lesions thickening the membrane when compared with normal control (Figure 1E).

Histologically, the skin showed hyperplasia, keratinization, and different stages of intracytoplasmic inclusion bodies (Figure 1B, C, D). The Chorioallantoic membrane (Figure 1H) showed hyperplasia of thickening allantoic cells. The previous lesions concentrate around blood vessels that appeared congested when compared with normal tissue (Figure 1F).

For molecular diagnosis, 50 tissue samples were collected from three different cases at Tikrit city and were subjected

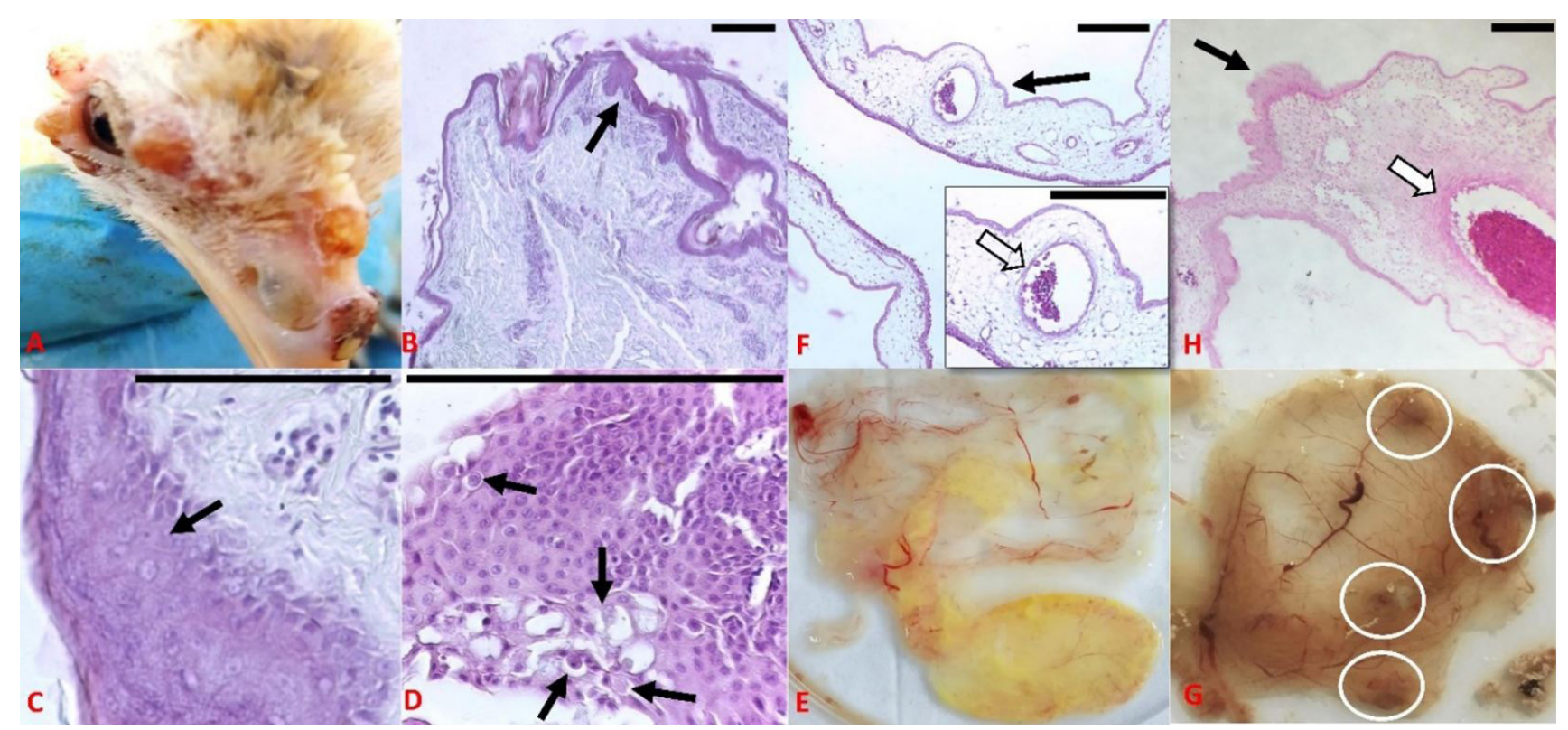

Figure 1. Dermal lesions of pox virus proliferation at face (A). Hyperplasia of skin epidermis (B). Hyperplasia of skin epidermis with excessive amounts of keratin (C). Intracytoplasmic inclusion bodies (D). Normal Chorioallantoic membrane (E). Normal Chorioallantoic membrane (black arrow) with normal arteriole (white arrow) (F). Dark grey lesions thicken the Chorioallantoic membrane (G). Thickened Chorioallantoic membrane (black arrow) and thickened congested arteriole (white arrow) (H). Pock lesion at the Chorioallantoic membrane. (Hematoxylin and Eosin staining; bar $=200 \mu \mathrm{m}$ ). 
to nested PCR technique to diagnose and confirm the presence of FPV. In the first reaction (Figure 2A), with external pair of primers (P1, P2), all but three samples at the lean 3,5 and 8 showed positive results as described by primer designers (Lee \& Lee, 1997). The current study results provide this evidence by successfully amplifying the 578 bp segment. At the second reaction (Figure 2B), with an internal set of primers (P3, P4), which produced a 419 bp segment (Fallavena et al., 2002), all samples successfully amplify the target band, which confirms the presence of FPV in the tested samples.

The products of the PCR results from the first set of primers (P1, P2) were sent for sequencing. One sequence (519 bp) was selected and submitted to GenBank under the accession number MN971579. The sequence of the current study aligned with 12 sequences published in the GenBank database (Figure 3). Analysis of aligned trimmed (486 bp) nucleotides showed (MH106510.1, MG787223.1,
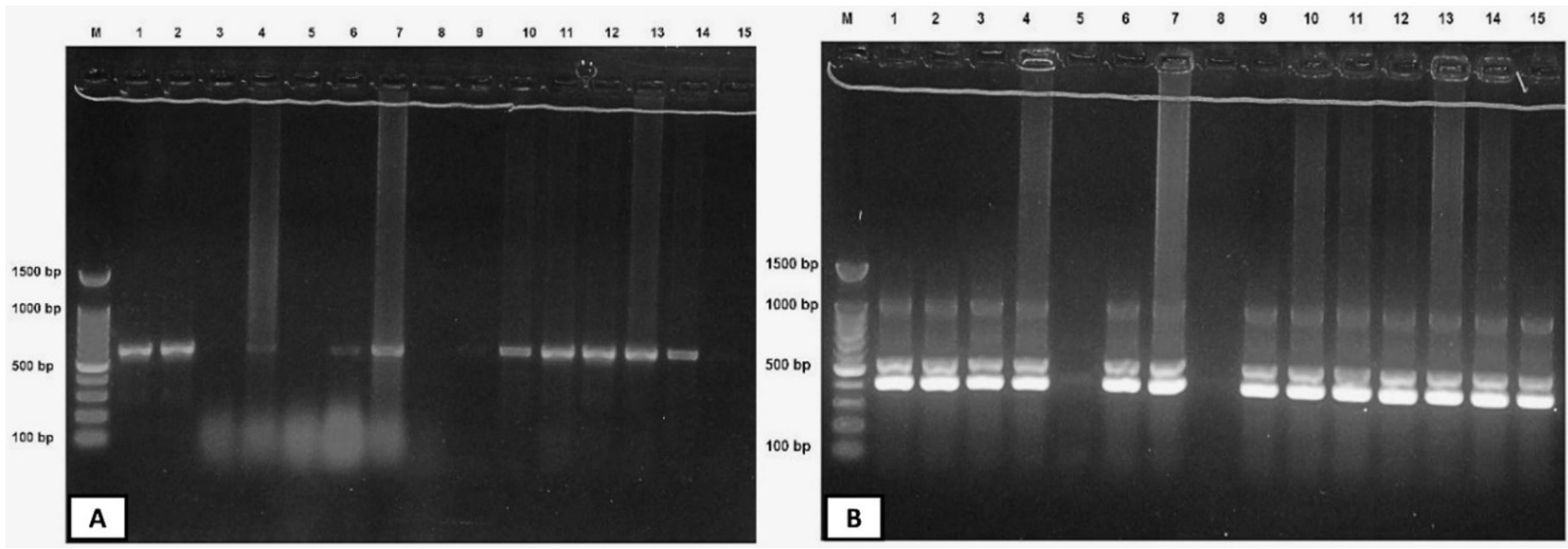

Figure 2. Agarose gel (1.5\%) electrophoresis of PCR product. A. P1, P2 primer; Len 1-15 FPV PCR product of 578 bp, Len M, Molecular weight marker 100-bp Ladder; B. P3, P4 primer; Len 1-15 FPV PCR product of 419 bp, Len M, Molecular weight marker 100-bp Ladder.

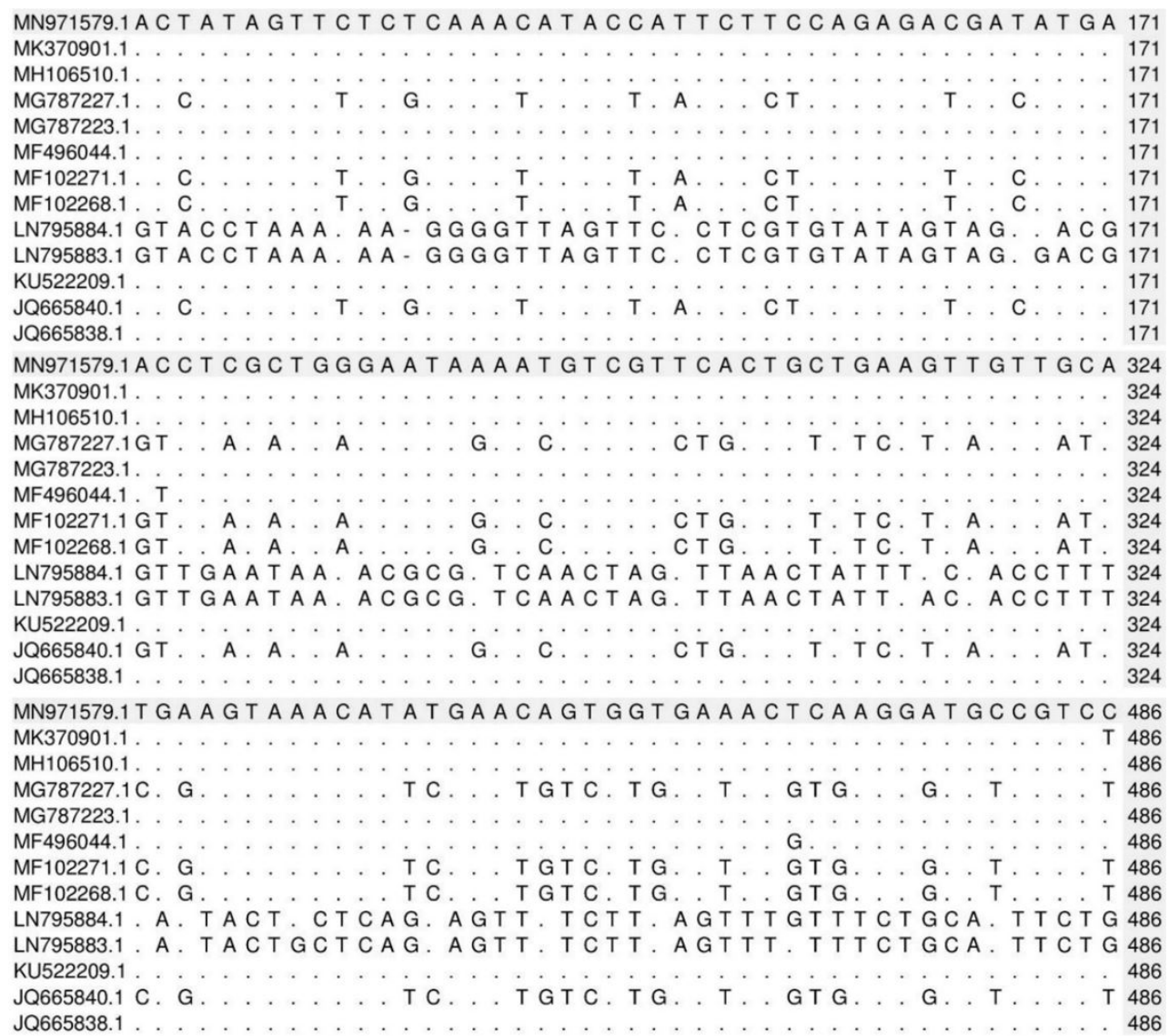

Figure 3. Showed 132 variable sites of regional 486 aligned nucleotides 199,529-201,502 (Afonso et al., 2000) of the P4b gene, locus FPV 167, while the invariable sites were deleted. The phylogenic NJ tree with Bootstrap value (1000 replicates) and confidence between clades $>79 \%$. 
KU522209.1, and JQ665838.1) 100\% identity with some aligned sequences, while other isolates had a variable range of homogeneity (MK370901.1 99.78\%, MF496044.1 99.58\%; MF102268.1, MG787227.1, MF102271.1 and JQ665840.1 $90.94 \%)$. On the other side, other virus isolates showed a more comprehensive range of variability (LN795884.1 76.33\%, LN795883.176.13\%). There were over 135 variable sites of all (13) sequences distributed as follows: $77.39 \%$ of nucleotides were non-mutated, while $22.61 \%$ of nucleotides were mutated. The mutation percentages of nucleotides allocated decadently as follows: $13.83 \%$ included transitions of $\mathrm{C}$ to $\mathrm{T} 5.35 \%$, A to $\mathrm{G} 3.53 \%$, T to C $2.73 \%$, G to A $2.22 \%$, while $8.78 \%$ of nucleotides included transversions type of mutation as follows: A to T $2.10 \%$, T to A $1.70 \%$, G to T $1.59 \%$, T to G $1.13 \%$, A to C $0.91 \%$, C to A $0.79 \%, \mathrm{G}$ to C $0.34 \%$, C to G $0.22 \%$.

The phylogenetic tree (Figure 4) showed that the 13 aligned trimmed nucleotides ( $486 \mathrm{bp}$ ) sequences of the virus from different regional bird species grouped into three clades. Clad A included viruses isolated from chicken and turkey, and clade B had viruses isolated from canary and rock dove. In contrast, clade $\mathrm{C}$ included viruses isolated from bustard and stone-curlew birds. The Iraqi isolate is grouped within clade A next to three Iranian isolates and an Egyptian one with a less far distance from the Indian isolates.

\section{Discussion}

The current study reported 50 cases from three different locations in the same city as positive as FPV using gross lesions, virus isolation, histological study tools. For further confirmation and analysis, PCR and sequencing were performed by targeting the widely used globally locus FPV 167 that produces an amplicon size of $578 \mathrm{bp}$. Phylogenic analysis results showed that the virus clustered at cluster A. We noticed that there is no molecular characterization study of the FPV in Iraq. However, decades before today, researchers discussed the importance of studying the zoonotic FPV in Iraq (Al-Hyali et al., 2005; Tantawi et al., 1981). One Iraqi researcher only described the effect of the virus on chicken CAM, tissue culture, and histopathological influence of the virus on chicken and other wild bird species (Bayati, 2017). Further analysis was made by the current study to find the relation between Iraqi virus isolate and viruses from the neighboring regional area depending on the FPV 167 loci of $\mathrm{P} 4 \mathrm{~b}$ gene sequences.

The histological and gross lesions of the affected chickens by FPV appeared as a classical lesion of nodular grey color on the skin, especially in the area between the eye and peak of the bird.

Histological hyperkeratosis, intracytoplasmic inclusions, and hyperplasia of the skin described by the current study were widely confirmed with FPV (Beytut \& Haligür, 2007; Murer et al., 2018). Researchers used lesions of poxvirus for isolation, purification, and a histopathological marker (Bayati, 2017). The results agree with earlier studies except for low pocks lesion number in the current study results, due to the positive relation of passage numbers and virulence of the virus (Gilhare et al., 2015). The CAM thickens blood vessels, which appear as a thrombosed resulting from virus replication in the membrane remarked by other researchers who also showed that the gross and histological results

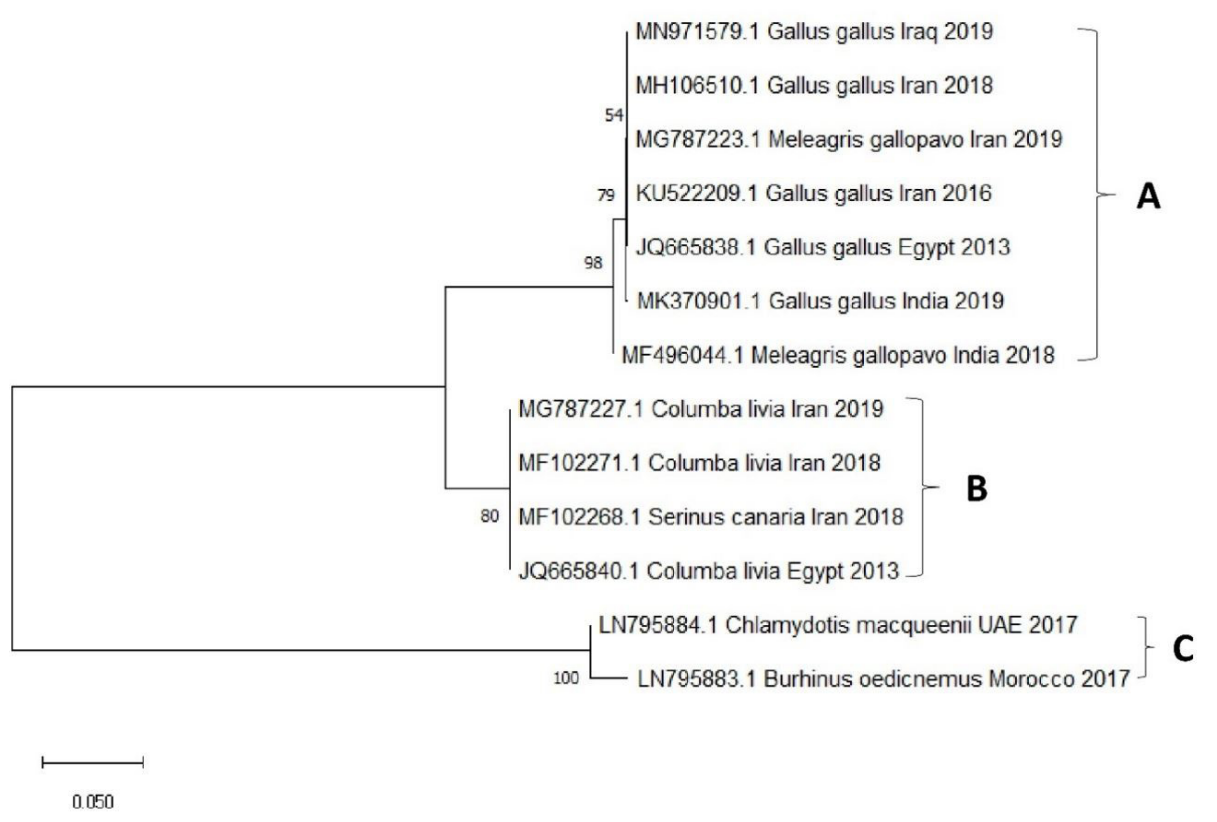

Figure 4. Phylogenic analysis of APV constricted using MEGAX software depending on FPV 167 loci of partial P4b gene nucleotides (486 bp) used for generation neighbor-joining tree using Tamura 3-parameter model with gamma distribution parameter of 0.38 and Bootstrap values (1000 replicate). 
alone are not sufficient to differentiate the virus, and further analysis should be performed (Sharma et al., 2019).

Molecular tools such as PCR became a famous combined test with other routine histopathological studies for diagnosis and analysis of FPV, especially the FPV 167 locus of the P4b gene (Offerman et al., 2013). Since the first sequence of the FPV P4b gene was published, researchers designed primers depending on this gene as a conservative gene (Binns et al., 1989; Lee \& Lee, 1997). The first reaction of 578bp (Figure 1A) of the current study using P1, P2 primer successfully amplified the target segment of the $\mathrm{P} 4 \mathrm{~b}$ gene. However, some samples (3,5,8,9 and 15) had shallow intensive bands, which appeared clearly at the second reaction of $419 \mathrm{bp}$ (Figure 1B). Several factors involved in productive PCR tests affect the intensity of amplicon, including primer depletion, low DNA templet, polymerase, and annealing/extension time, which play a significant role in PCR plateau formation. The amplification also could be hampered by increased amounts of non-target amplicons that correlated with the size of the amplicon (Jansson \& Hedman, 2019). Annealing temperature and preamplification reaction, which significantly reduces the non-specific bands, affects the productivity of PCR (Andersson et al., 2015). The second reaction of $\mathrm{P} 3, \mathrm{P} 4$ internal primer increases the factors that support successful amplification, leads to more accurate detection of FPV with new reaction ingredients. Fallavena et al., 2002 showed that the second reaction increased the sensitivity of the test for less than one infectious unit.

Nucleotides sequence alignments showed three Iranian and one Egyptian virus isolates from chicken hosts identical to the Iraqi FPV isolate despite the FPV 167 locus characteristic as a conservative region (Yeo et al., 2019). The similarity between isolates could result from close borders and trade between neighboring countries. The massive transition to transversion rates depends on the replication mechanism of the given virus. Still, it is known that viruses of short evolutionary distances appear to have more transition rather than transversions that became more prominent when the length extends (Domingo, 2020). The large genomic size of IPV, which is about $288 \mathrm{Kbp}$. (Afonso et al., 2000), needs high financial requirements for complete genome sequencing. This study highlighted the necessity for a reliable and straightforward, less conservative genome segment describing the homogeneity and variability between FPV isolates in the area of study.

Phylogenic tree analysis using the NJ tree model based on locus FPV 167 of the P4b gene is widely used for the phylogenetic classification of FPV. Regardless of the conservative nature of the locus FPV 167, we confirmed that this locus is useful for clade sorting, and another locus like FPV 140 is supportive for further subclade classifications (Abdallah \& Hassanin, 2013). The current nucleotidesbased NJ tree showed that the aligned viruses sequences clustered in three clades, and Iraqi FPV isolate grouped in clade A with other chickens. Turkey FPV isolates are closest to Iranian and Egyptian isolates and relatively far from the Indian isolates. These results agree with a group of researchers who classified FPV clades into clade A (Fowlpox virus), including mainly Galliformes and Columbiformes order, clade B (Canarypox virus), and clade C (Psittacinepox virus) (Jarmin et al., 2006; Manarolla et al., 2010). Columba livia in the current study arranged in clade B and wild birds from Morocco and UAE set in separated clade C, which is mentioned by most researchers as a subclade of clade B (Ferreira et al., 2018; Le Loc'H et al., 2014). Clade C appeared as a separated clade in the current study because of the extensive genetic distance of the wild birds' viruses in comparison with other poxviruses aligned sequences. Clade $\mathrm{C}$ would classify as a subclade of clade $\mathrm{B}$ canarypoxlike viruses if there were more regional sequences aligned with the current sequences (Le Loc'h et al., 2015).

\section{Conclusion}

Poxvirus was the causative of chicken dermal pock lesions. The second nested PCR is a highly sensitive test. The FPV 167 is a practical locus for phylogenetic analysis. Low regional data of FPV limits the phylogenetic tree analysis. There are different identities between Iraqi, Iranian, and Egyptian FPV. Mutations appeared clearly in a small segment of the conservative gene.

\section{Declaration of Competing Interest}

The authors declare they have no conflict of interest.

\section{Ethics Statement}

The research was conducted under the approval of the Scientific Committee of Veterinary Medicine Collage, Tikrit University.

\section{Acknowledgements}

We thank the Central laboratory of Tikrit University for technical support. We also thank the college of veterinary medicine and Salah-adin veterinary teaching hospital for their productive cooperation that supports the research. 


\section{References}

Abdallah FM, Hassanin O. Detection and molecular characterization of avipoxviruses isolated from different avian species in Egypt. Virus Genes. 2013;46(1):63-70. http:// dx.doi.org/10.1007/s11262-012-0821-y. PMid:22996736.

Afonso CL, Tulman ER, Lu Z, Zsak L, Kutish GF, Rock DL. The genome of fowlpox virus. J Virol. 2000;74(8):381531. http://dx.doi.org/10.1128/JVI.74.8.3815-3831.2000. PMid:10729156.

Al-Hyali MH, Al-Zughaibi AB, Abdulkarim S. Cytopathogenicity studied of fowl pox virus by using indirect immunoperoxidase and acridine orange tests. Iraqi J Vet Medi. 2005;29(2):12-20.

Andersson D, Akrap N, Svec D, Godfrey TE, Kubista M, Landberg G, Ståhlberg A. Properties of targeted preamplification in DNA and cDNA quantification. Expert Rev Mol Diagn. 2015;15(8):1085-100. http://dx.doi.org/10 .1586/14737159.2015.1057124. PMid:26132215.

Bayati HAMA. Virological Study about Avipox virus in Local Birds of Iraq. Int J Sci Res (Ahmedabad). 2017;6(6):766-9. http://dx.doi.org/10.21275/ART20174307.

Beytut E, Haligür M. Pathological, immunohistochemical, and electron microscopic findings in the respiratory tract and skin of chickens naturally infected with avipoxvirus. Turk J Vet Anim Sci. 2007;31(5):311-7.

Binns MM, Boursnell MEG, Tomley FM, Campbell J. Analysis of the fowlpoxvirus gene encoding the $4 \mathrm{~b}$ core polypeptide and demonstration that it possesses efficient promoter sequences. Virology. 1989;170(1):288-91. http:// dx.doi.org/10.1016/0042-6822(89)90380-2. PMid:2541544.

Carulei O, Douglass N, Williamson AL. Comparative analysis of avian poxvirus genomes, including a novel poxvirus from lesser flamingos (Phoenicopterus minor), highlights the lack of conservation of the central region. BMC Genomics. 2017;18(1):1-13. http://dx.doi.org/10.1186/ s12864-017-4315-0. PMid:29207949.

Domingo E. Virus as Populations. 2nd ed. Academic Press: 2020. Chapter 2 - Molecular basis of genetic variation of viruses: error-prone replication; p. 35-71. http://dx.doi. org/10.1016/b978-0-12-816331-3.00002-7.

Fallavena LCB, Canal CW, Salle CTP, Moraes HLS, Rocha SLS, Pereira RA, Silva AB. Presence of avipoxvirus DNA in avian dermal squamous cell carcinoma. Avian Pathol.
2002;31(3):241-6. http://dx.doi.org/10.1080/03079450220136558. PMid:12396347.

Fenner F, Pereira HG, Porterfield JS, Joklik WK, Downie AW. Family and generic names for viruses approved by the International Committee on Taxonomy of Viruses, June 1974. Intervirology. 1974;3(3):193-8. http://dx.doi. org/10.1159/000149755. PMid:4443189.

Ferreira BC, Ecco R, Couto RM, Coelho HE, Rossi DA, Beletti ME, Silva PL. Outbreak of cutaneous form of avian poxvirus disease in previously pox-vaccinated commercial turkeys. Pesq Vet Bras. 2018;38(3):417-24. http://dx.doi. org/10.1590/1678-5150-pvb-4463.

Gilhare VR, Hirpurkar SD, Kumar A, Naik SK, Sahu T. Pock forming ability of fowl pox virus isolated from layer chicken and its adaptation in chicken embryo fibroblast cell culture. Vet World. 2015;8(3):245-50. http://dx.doi. org/10.14202/vetworld.2015.245-250. PMid:27047081.

Giotis ES, Skinner MA. Spotlight on avian pathology: fowlpox virus. Avian Pathol. 2019;48(2):87-90. http://dx.doi.org/10 .1080/03079457.2018.1554893. PMid:30507248.

Jansson L, Hedman J. Challenging the proposed causes of the PCR plateau phase. Biomol Detect Quantif. 2019;17(February):100082. http://dx.doi.org/10.1016/j. bdq.2019.100082. PMid:30886826.

Jarmin S, Manvell R, Gough RE, Laidlaw SM, Skinner MA. Avipoxvirus phylogenetics: identification of a PCR length polymorphism that discriminates between the two major clades. J Gen Virol. 2006;87(8):2191-201. http://dx.doi. org/10.1099/vir.0.81738-0. PMid:16847115.

Laidlaw SM, Skinner MA. Comparison of the genome sequence of FP9, an attenuated, tissue culture-adapted European strain of Fowlpox virus, with those of virulent American and European viruses. J Gen Virol. 2004;85(2):30522. http://dx.doi.org/10.1099/vir.0.19568-0. PMid:14769888.

Lebdah M, Ali AM, Ali AA, Hassanin O. Insights into pathological and molecular characterization of avipoxviruses circulating in Egypt. Br Poult Sci. 2019;60(6):666-74. http:// dx.doi.org/10.1080/00071668.2019.1639141. PMid:31298555.

Lecis R, Secci F, Antuofermo E, Nuvoli S, Cacciotto C, Pittau M, Alberti A. Detection and characterization of an Avipoxvirus in a Common Buzzard (Buteo buteo) in Italy 
using a multiple gene approach. J Wildl Dis. 2019;55(1):1428. http://dx.doi.org/10.7589/2017-10-265. PMid:29953311.

Lee LH, Lee KH. Application of the polymerase chain reaction for the diagnosis of fowl poxvirus infection. J Virol Methods. 1997;63(1-2):113-9. http://dx.doi.org/10.1016/ S0166-0934(96)02119-2. PMid:9015281.

Le Loc'h G, Bertagnoli S, Ducatez MF. Time scale evolution of avipoxviruses. Infect Genet Evol. 2015;35:75-81. http:// dx.doi.org/10.1016/j.meegid.2015.07.031. PMid:26231721.

Le Loc'H G, Ducatez MF, Camus-Bouclainville C, Guérin JL, Bertagnoli S. Diversity of avipoxviruses in captive-bred Houbara bustard. Vet Res (Faisalabad). 2014;45(1):98. http:// dx.doi.org/10.1186/s13567-014-0098-3. PMid:25270742.

Manarolla G, Pisoni G, Sironi G, Rampin T. Molecular biological characterization of avian poxvirus strains isolated from different avian species. Vet Microbiol. 2010;140(12):1-8. http://dx.doi.org/10.1016/j.vetmic.2009.07.004. PMid:19646826.

Murer L, Westenhofen M, Kommers GD, Furian TQ, Borges KA, Kunert-Filho HC, Streck AF, Lovato M. Identification and phylogenetic analysis of clade $\mathrm{C}$ Avipoxvirus in a fowlpox outbreak in exotic psittacines in southern Brazil. J Vet Diagn Invest. 2018;30(6):946-50. http://dx.doi. org/10.1177/1040638718775146. PMid:30199325.

Offerman K, Carulei O, Gous TA, Douglass N, Williamson AL. Phylogenetic and histological variation in avipoxviruses isolated in South Africa. J Gen Virol. 2013;94(Part 10):233851. http://dx.doi.org/10.1099/vir.0.054049-0. PMid:23860490.

Ruiz-mart1 J, Alexander R, Williams J, Herrera-due A, Escudero C, Aguirre I, Benı L. Prevalence and genetic diversity of avipoxvirus in House Sparrows in Spain. Plos One. 2016;11(12):1-13. http://dx.doi.org/10.1371/journal. pone. 0168690

Sharma B, Nashiruddullah N, Ahmed JA, Sharma S, Ahamad DB. Pathology of Avipoxvirus isolates in chicken embryonated eggs. Int J Curr Microbiol Appl Sci. 2019;8(09):422-30. http://dx.doi.org/10.20546/ijcmas.2019.809.051.

Soud A, Ibrahim I, El-moaty A. Antigenic and genomic characterization of local fowlpox virus isolate in 2017. J Appl Anim Res. 2020;5(3):31-9.

Suvarna KS, Layton C, Bancroft JD. Bancroft's theory and practice of histological techniques. China: Churchill Livingstone; $2013.654 \mathrm{p}$.

Tantawi HH, Al Sheikhly S, Hassan FK. Avian pox in buzzard (Accipiter nisus) in Iraq. J Wildl Dis. 1981;17(1):145-6. http:// dx.doi.org/10.7589/0090-3558-17.1.145. PMid:6265658.

Yeo G, Wang Y, Chong SM, Humaidi M, Lim XF, Mailepessov D, Chan S, How CB, Lin YN, Huangfu T, Fernandez CJ, Hapuarachchi HC, Yap G. Characterization of Fowlpox virus in chickens and bird-biting mosquitoes: A molecular approach to investigating avipoxvirus transmission. J Gen Virol. 2019;100(5):838-50. http://dx.doi.org/10.1099/ jgv.0.001209. PMid:30907721.

Zou Z, Zhang J. Morphological and molecular convergences in mammalian phylogenetics. Nat Commun. 2016;7(1):1-9. http://dx.doi.org/10.1038/ncomms12758. PMid:27585543.

Financial Support: The authors did not receive a grant from any organization to fund the research. 